\title{
PEMBELAJARAN KEMUHAMMADIYAHAN : EVALUASI PROGRAM DI UNIVERSITAS MUHAMMADIYAH PROF. DR. HAMKA (UHAMKA)
}

\author{
Almisar Hamid \\ Fakultas Ilmu Sosial dan Ilmu Politik Universitas Muhammadiyah Jakarta \\ almi.fisip@gmail.com
}

\section{ABSTRACT}

The purpose of this research is to evaluation the implementation of the Muhammadiyah learning program which is a compulsory subject in all Muhammadiyah and Aisyiah Universities (PTMA). The research was conducted at the University of Muhammadiyah Prof. Dr. Hamka (Uhamka) in January to April 2020. This research is a qualitative research. The informants were selected using a purposive technique, consisting of students, lecturers, Uhamka leaders, and the leadership of the PP Muhammadiyah Diktilitbang Council. Data were collected by using interview techniques, Focused Group Discussion (FGD), and documentation. The data were analyzed by evaluating the CIPP Stufflebeam model.

The results of the study show that there are still a number of obstacles in the learning of Muhammadiyah, among others, in terms of context, there are still debates about the content of the curriculum. Renewal efforts have been made with the publication of new textbooks. From the input side, there were obstacles regarding the availability, qualifications, and certification of Kemuhammadiyahan lecturers. In terms of process, the duration of learning which is only 2 credits is felt to be insufficient to implement learning with empowerment strategies. Finally, in terms of products, despite the development of student views about Muhammadiyah, these developments have not significantly changed the religious traditions they believe in so far.

Keywords: Program Evaluation, learning, Al Islam Kemuhammadiyahan.

\section{ABSTRAK}

Tujuan penelitian ini adalah untuk mengevaluasi penyelenggaraan program pembelajaran Kemuhammadiyahan yang menjadi mata kuliah wajib di seluruh Perguruan Tinggi Muhammadiyah dan Aisyiah (PTMA). Penelitian dilakukan di Universitas Muhammadiyah Prof. Dr. Hamka (Uhamka) pada bulan Januari sampai dengan April 2020. Penelitian evaluatif ini adalah penelitian kualitatif. Informan dipilih dengan teknik purposive, terdiri dari unsur mahasiswa, dosen, pimpinan Uhamka, dan Pimpinan Majelis Diktilitbang PP Muhammadiyah. Data dikumpulkan dengan teknik wawancara, Focused Group Discussion (FGD), dan dokumentasi. Data dianalisis dengan evaluasi model CIPP Stufflebeam.

Hasil penelitian menunjukkan masih ditemukan sejumlah kendala dalam pembelajaran Kemuhammadiyahan, antara lain dari sisi konteks, masih terjadi perdebatan mengenai muatan isi kurikulum. Upaya pembaharuan sudah dilakukan dengan diterbitkaannya buku ajar baru. Dari sisi input ditemui kendala menyangkut ketersediaan, kualifikasi, dan sertifikasi dosen Kemuhammadiyahan. Dari sisi proses, durasi waktu pembelajaran yang hanya 2 sks dirasakan tidak cukup untuk menerapkan pembelajaran dengan strategi pemberdayaan. Terakhir, dari sisi produk, kendati terjadi perkembangan pandangan mahasiswa tentang Muhammadiyah, namun perkembangan tersebut belum mengubah secara signifikan tradisi keagamaan yang mereka yakini selama ini.

Kata kunci: Evaluasi Program, pembelajaran, Al Isalam Kemuhammadiyahan. 


\section{PENDAHULUAN}

Al Islam dan Kemuhammadiyahan (AIK) adalah mata kuliah wajib yang harus diikuti oleh mahasiswa yang belajar di perguruan Tinggi Muhammadiyah dan Aisyiah (PTMA). Dengan mempelajari AIK mahasiswa diharapkan akan memiliki kompetensi yang tidak hanya dalam bidang ilmu dan teknologi tetapi juga berkarakter Islami. Untuk mencapai tujuan ini tentu saja diperlukan suatu rancangan program pembelajaran yang memadai.

Dalam praktek pembelajaran AIK ditemukan sejumlah kelemahan dan kendala yang menghambat pencapaian tujuan tersebut. Berdasarkan pengamatan di beberapa PTMA dapat dikemukakan temuan sebagai berikut. Dilihat dari Kurikulum dan sillabus diketahui bahwa (a) kurikulum belum dirancang secara memadai dengan mengikuti prinsip rancangan pembelajaran yang sistematis sehingga tidak tampak keterkaitannya dengan visi misi institusi, (b) pembelajaran terbatas pada kawasan pengetahuan (knowledge), hampir tidak ditemukan pembelajaran di kawasan sikap (afectif) dan Perilaku (psikomotoric), (c) materi pembelajaran sering diulang-ulang, (d) tidak tampak relevansi antara tujuan, metode, materi ajar, dan evaluasi. Dilihat dari kualifiksai dan kompetensi dosen pengampu diketahui (a) tidak direncanakan sesuai kebutuhan pembelajaran dan tuntutan perkembangan zaman, (b) belum ditemukan sertifikasi dosen pengampu AIK, (c) belum semua program studi memiliki dosen tetap AIK, (d) dalam proses pembelajaran belum optimal memanfaatkan multi media. Selanjutnya dilihat dari sumber belajar dapat dikemukakan (a) sangat terbatas referensi dan buku teks yang memadai, (b) tidak tersedia media pembelajaran multimedia. Dilihat dari perspektif kebijakan dapat dikemukakan (a) diperlukan dukungan yang kuat dari pimpinan PTMA, dan (b) diperlukan aturan tertulis tentang kebijakan AIK bagi mahasiswa non muslim.
Menurut Zamah Sari, pimpinan Uhamka dan Ketua Tim Penyusun Buku Ajar Baru Kemuhammadiyahan pada acara up grading dosen-dosen Kemuhammadiyahan UMJ Jumat 22 Pebruari 2019, di Uhamka pembelajaran Kemuhammadiyahan tidak menarik di mata mahasiswa. Setidaknya disebabkan oleh dua hal, yaitu (a) materi pembelajaran yang monoton di seputar sejarah Muhammadiyah, organisasi otonomnya, dan ideologi, dan (b) Sebagian besar mahasiswa Uhamka adalah milenial dan bukan berasal dari keluarga Muhammadiyah.

Memperhatikan realitas pembelajaran sebagaimana dikemukakan di atas, 10 PTM merancang model baru pembelajaran Kemuhammadiyahan dan bahan pembelajarannya. Dalam rancangan yang baru tersebut materi pembelajaran mencakup tiga domain pembelajaran Kemuhammadiyahan yaitu domain pengetahuan, sikap, dan perilaku yang tertuang dalam 11 pokok bahasan Kemuhammadiyahan, yaitu : (1) Pembelajaran Kemuhammadiyahan: Memampukan umat dengan kedermawanan, (2) Tauhid Al-Ma'un dalam kehidupan bermasyarakat, (3) Ajakan yang mencerahkan dan pembangunan keluarga, (4) Cara cara jangka panjang menemukan keluarga yang hidup dengan kemiskinan, (5) Panduan menyusun usulan dakwah dengan sasaran kelompok duafa, (6) Penghimpunan dana bagi pemberdayaan keluarga miskin, (7) Penyerahan dana pemberdayaan untuk keluarga duafa, (8) Islam berkemajuan menuju Indonesia berkemajuan, (9) Ideologi Muhammadiyah, (10) Tiga pilar dakwah Muhammadiyah; pendidikan, kesehatan dan ekonomi, dan (11) Peran strategis dan Tantangan Muhammadiyah (Tim Dosen Penulis AIK, 2018).

Setelah buku tersebut di launching oleh Ketua Pimpinan Pusat Muhammadiyah pada 10 Desember 2018, Uhamka adalah PTM pertama yang mempraktekan pembelajaran Kemuhammadiyahan dengan rancangan 
dan pendekatan baru yang dipandang sesuai dengan kebutuhan organisasi dan tuntutan perkembangan zaman.

Di Universitas Muhammadiyah Jakarta (UMJ), home base peneliti, dirasakan pula kebutuhan untuk memperbaharui program pembelajaran AIK. Untuk itu dilakukan penelitian evaluatif penyelenggaraan program pembelajaran Kemuhammadiyahan di Uhamka sebagai bahan masukan dalam rencana pembaharuan tersebut.

\section{KAJIAN TEORETIK}

\section{Pendidikan dan Pendidikan Agama Islam}

Pendidikan menurut Suradika (2019: 17) adalah usaha sadar yang dilakukan orang atau sekelompok orang untuk menyiapkan peserta didik melalui kegiatan bimbingan, pengajaran, dan/atau latihan untuk kebutuhannya di masa yang akan datang. Berkaitan dengan Pendidikan Agama, menurut Suradika, dkk (2020: 1030), sikap dan perilaku peserta didik merupakan kemampuan yang juga harus dikuasai selain penguasaan di ranah kognitif.

Amie Primani dan Khairunnas (2013: 223-225) mengemukakan tujuh nilai yang mendasari Pendidikan Agama Islam, yaitu nilai ibadah, nilai ihsan, nilai masa depan, nilai kerahmatan, nilai amanah, nilai dakwah, dan nilai tabsyir.

\section{Pembelajaran Al Islam dan Kemuhammadiyahan}

Pembelajaran Al Islam dan Kemuhammadiyahan (AIK) di Perguruan Tinggi Muhammadiyah dan Aisyiah (PTMA) memiliki posisi strategis, menjadi ruh penggerak dan misi utama penyelenggaraan PTMA (Majelis Pendidikan Tinggi Muhammadiyah, 2013: 10). AIK di PTMA memandang Islam sebagai petunjuk kepada jalan yang lurus, modal sosial, jalan menuju Tuhan dan jalan kebahagiaan di dunia dan akhirat. Lebih lanjut dikemukakan oleh Majelis Pendidikan Tinggi Muhammadiyah bahwa tujuan pembelajaran AIK adalah untuk membentuk insan berkarakter dan insan terpelajar yang diharapkan memiliki integritas dan kesadaran etis.

Masih menurut Majelis Pendidikan Tinggi Muhammadiyah (2010), model pembelajaran AIK dikembangkan dengan prinsip student centered learning yang menempatkan mahasiswa sebagai subyek pembelajar dan pemeran utama pembelajaran yang menemukan sendiri nilai-nilai AIK. Ia menjadi aktor dan mitra dosen. Selanjutnya Dosen menjadi role model dan pemimpin kelas, yang dituntut memiliki integritas moral dan intelektual sehingga mampu menjadi teladan, dan sebagai pemimpi kelas berperan sebagai fasilitator yang memberikan pengarahan, pencerahan, dan memotivasi mahasiswa.

Berkaitan dengan kualitas pembelajaran AIK, Majelis Dikti Muhammadiyah menetapkan Standar mutu AIK atas dasar pemikiran (a) bidang AIK adalah basis seluruh kegiatan akademik dan non akademik di PTMA, (b) bidang AIK harus tampil menjadi ciri khas yang kuat dan terukur bagi PTMA, (c) bidang AIK harus hadir dengan pendekatan yang menarik dan menyenangkan sehingga dakwah di kampus berlangsung dengan normal.

\section{METODOLOGI PENELITIAN}

Penelitian ini dilakukan di Universitas Muhammadiyah Profesor Dr. Hamka (Uhamka), kampus Limau, Kebayoran Baru Jakarta Selatan, dan kampus Pasar Rebo Jakarta Timur. Pengumpulan data dilaksanakan pada Januari-April 2020. Penelitian ini adalah penelitian evaluatif dengan pendekatan kualitatif.

Model evaluasi yang digunakan adalah model evaluasi CIPP Stufflebeam (Suradika dan Wicaksono, 2019: 213214). Teknik pengumpulan data yang digunakan adalah wawancara, Focused Group Discussion (FGD), observasi, dan dokumentasi. Informan dipilih dengan teknik purposivie, yakni mereka yang dipandang mempunyai sangkut paut yang erat dengan ciri-ciri atau sifat-sifat populasi yang sudah diketahui sebelumnya (Suradika, 2000:43), terdiri dari dosen, mahasiswa, pimpinan 
Uhamka, dan pimpinan Majelis Pendidikan Tinggi Penelitian dan Pengembangan Pimpinan Pusat Muhammadiyah. Untuk menguji keavsahan data dilakukan triangulasi.

Sebagaimana model evaluasi yang dipilih, analisis data dilakukan dengan menggunnakan model CIPP (Context, Input, process dan Product) dari stufflebeam dengan penjelasan sebagai berikut: Pertama, evaluasi konteks terhadap program pembelajaran Kemuhammadiyahan. Pada tahap ini dikumpulkan informasi tentang alasanalasan diadakannya model pembelajaran terhadap mata kuliah Kemuhammadiyahan. Bagaimana dukungan institusional terhadap mata kuliah al Islam Kemuhammadiyahan. Kedua, evaluasi Input. Pada tahap ini dikumpulkan informasi mengenai peserta didik atau mahasiswa dengan pengetahuan yang diperoleh dari penerapan bahan pembelajaran kemuhammadiyahan baru atau karakteristik dan kompetensi awal peserta didik mata kuliah Kemuhammadiyahan. Ketiga, evaluasi proses. Pada tahap ini dikumpulkan informasi mengenai proses di kelas dan pembelajaran di lapangan (pemberdayaan keluarga duafa) melalui kelompok mahasiswa. Utamanya dalam proses ini dikumpulkan informasi: (1) kesiapan tenaga pendidik/dosen untuk mengampu mata kuliah ini dan pendampingan pemberdayaan keluarga duafa, dan (2) bahan pembelajaran, lingkungan belajar dan strategi pembelajaran. Terakhir, Keempat untuk evaluasi produk adalah pengetahauan dan ketrampilan sebagai capaian yang diharapkan. Sebagai mana diketahui, pada bahan ajar Kemuhammadiyahan baru ini dijelaskan capaian yang diharapkan bagi mahasiswa yaitu: (1) mampu menerapkan model dakwah pencerahan untuk keluarga duafa, (2) mampu memahami dimensi - dimensi dan hasil gerakan Muhammadiyah, dan (3) mampu menginternalisasi nilai -nilai dasar muslim berkemajuan.

\section{HASIL DAN PEMBAHASAN}

\section{Evaluasi Konteks (Context evalution)}

Evaluasi konteks adalah dasar evaluasi untuk menghadirkan beberapa alasan (rationale) terkait program yang dievaluasi. Pembelajaran AIK khususnya Kemuhammadiyahan sejak awal sudah dirancang berdasarkan riset sebelumnya di mana salah satu kendalanya adalah tidak menariknya materi ajar yang ada. Hal itu diperkuat lagi dengan mahasiswa yang belajar di UHAMKA sebagian besar bukan anak-anak yang berasal dari keluarga Muhammadiyah yang dapat diketahui dari bacaan ibadah sholatnya yang kebanyakan membaca "Kabiira" atau "wajjahtu" ketika do'a iftitah, sedangkan tuntutan ibadah sebagaimana keputusan Tarjih Muhammadiyah, bacaan dalam doa iftitah adalah membaca "Allahumma baa'id".

Sebelumya pada pedoman pendidikan AIK yang diterbitkan oleh MAJELIS DIKTI (Tim Pedoman Pendidikan Al Islam dan Kemuhammadiyahan Majelis Pendidikan Tinggi PP Muhammadiyah, 2013), juga dijelaskan bahwa pembelajaran AIK menghadapi banyak persoalan sebagaimana telah dijelaskan di bagian pendahuluan tulisan ini. Hal itulah yang mendasari adanya pembaharuan dalam pembelajaran AIK khususnya Kemuhammadiyahan. Jika diurut berdasarkan permasalahan di atas, tentu belum seberapa pembaharuan yang dilakukan. Tetapi sudah ada; antara lain telah menyiapkan buku ajar yang siap digunakan oleh para tenaga pendidik/dosen. Dan Tenaga pendidik/dosen sudah dinilai oleh pimpinan

\section{Evaluasi Input (Input Evaluation)}

Evaluasi input (input evaluation) bertujuan menyediakan informasi untuk menentukan bagaimana menggunakan sumberdaya yang tersedia untuk mencapai tujuan. Evaluasi meliputi analisis personal yang berkaitan dengan bagaimana penggunaan sumber-sumber yang ada, alternatif strategi yang mesti ditimbang-timbang untuk mencapai suatu program. Mengidentifikasi dan menaksir sistem, alternatif strategi, 
desein prosedur untuk strategi penerapan, pembiayaan dan penjadwalan. Manfaat dari Evaluasi masukan adalah untuk membimbing pemilihan strategi dalam menspesifikasikan rancangan prosedural. Informasi dan data yang terkumpul dapat dipakai untuk menentukan sumber dan strategi dalam keterbatasan yang ada. Pertanyaan yang mendasar adalah bagaimana rencana penggunaan sumbersumber yang ada sebagai usaha menemukan rencana program yang efektif dan efisien.

Berdasarkan konsep evaluasi input di atas, ada beberapa hal yang dapat digunakan untuk dijadikan alat analisis seperti pembiayaan program dan pemilihan strategi. Berdasarkan data lapangan, sumber daya tenaga pendidik Kemuhammadiyahan yang tersedia dari segi ideologi Muhammadiyah sudah memadai. Hanya dari jabatan fungsional kebanyakan Asisten Ahli - Lektor, belum ada yang Lektor Kepala, apalagi Guru Besar. Sedangkan yang diharapkan di masa datang, jabatan fungsional tenaga pendidik adalah lektor kepala dan jika dapat adalah guru besar.

Terkait pembiayaan program dan pemilihan strategi, berdasarkan keterangan salah seorang pimpinan UHAMKA, ada rencana mau mengajukan kerja sama dengan pemerintah dan non pemerintah untuk dakwah lapangan dalam bentuk pemberdayaan keluarga tersebut. Sebab model kuliah Kemuhammadiyahan yang sekarang dimana belajar kepada $\mathrm{KH}$ Ahmad Dahlan dalam mengimplementasikan surat Al Maaun dalam pemberdayaan membutuhkan biaya. Tidak ada salahnya dicoba UHAMKA megajukan kerja sama dengan pemerintah dan non pemerintah (perusahaan - perusahaan ) dalam pembiayaan keluarga duafa, bahkan ini menolong pemerintah. Sekalipun hanya 1 keluarga per kelompok yang diberdayakan, tetapi dalam penentuan 1 keluarga tersebut sudah melalui kesepakatan kelompok. Artinya lebih obyektif dan dapat dikatakan sudah tepat sasaran. Sehingga dana yang diberikan kepada 1 keluarga per kelompok juga tepat sasaran. Berbeda dengan pemerintah dalam penentuan kelompok sasaran; datanya adalah data statistik dan diserahkan kepada perangkat desa/keluarhan. Siapa yang menjamin dana bantuan tepat sasaran. Jadi strategi pelaksanaan program ke depan dengan mengajukan kerja sama merupakan input yang dalam konteks evaluasi input/masukan

\section{Evaluasi Proses (Process Evaluation)}

Diterapkan untuk menilai pelaksanaan kegiatan, apakah program sudah sesuai dengan strategi. Juga untuk melakukan identifikasi masalah suatu kejadian. Perubahan yang terjadi perlu dimonitor secara obyektif. Catatan kegiatan penting dilaksanakan sebab bermanfaat untuk mengambil sikap. Penemu CIPP juga menjelaskan bahwa evaluasi ini adalah untuk pengawasan berkelanjutan atas implementasi perencanaan (Stufflebeam \& Shienfield, 1985:175 dalam Badrujaman, 2009:66). Melakukan identifikasi merupakan tujuan dalam proses penerapan, seperti cacat dalam implementasinya (Badrujaman, 2009). Berikut untuk menghadirkan info sebagai bahan memperbaiki program yaitu: (a) Kelemahan dapat diketahui sepanjang implementasi termasuk yang layak dipertahankan, (b) Mendapatkan info tentang keputusan yang diambil, dan (c) catatan-catatan lapangan mengenai hal penting perlu dijaga saat dilaksanakan.

Bertolak dari ketiga hal itu, proses pembelajaran Kemuhammadiyahan seperti dijelaskan di atas ditemukan beberapa kelemahan. Beberapa dosen mengatakan soal waktu atau jam yang disediakan dilapangan. Jika kuliah di lapangan betul sebagai pemberdayaan, maka waktu SKS yang diberikan tidak cukup 2 SKS dimana waktunya hanya 90 menit. Sebagai diketahui, meminjam konsep manajemen pemberdayaan dimana tahap pertama yang dilakukan oleh pelaku pemberdayaan adalah penyadaran kepada calon yang diberdayakan. Penyadaran ini penting karena jika keluarga duafa tidak sadar akan masalahnya sulit program 
pemberdayaan akan diteruskan. Tahap kedua adalah penyusun perencanaan bersama keluarga yang akan diberdayakan. Dalam tahap ini need assesment menjadi sangat penting. Masalah dan potensi yang dimiliki calon keluarga duafa yang diberdayakan perlu digali se dalam mungkin. Salah dalam melakukan assesment akan berpengaruh pada tahap pemberdayan selanjutnya. Tahap ketiga adalah pengorganisasian pemberdayaan. Pada tahap ini kelompok pemberdaya (kelompok mahasiswa) yang berjumlah 3 orang berbagi tugas; siapa melakukan apa bersama keluarga yang diberdaykan. Tentunya sesuai dengan masalah dan potensi kelarga duafa tersebut. Tahap keempat adalah (actuating) atau pelaksanaan kegiatan pemberdayaan. Misalnya pemberian motivasi atau pelatihan terhadap keluarga duafa tersebut. Tujuannya agar keluarga duafa tersebut memiliki semangat membangun kemandirian hidup di masa depan atau berdikari (meminjam istilah almarhum Presiden Sukarno). Fakta di lapangan, karena waktu terbatas, tahap pemberdayaan seperti sulit dilakukan oleh mahasiswa; Sekalipun pada buku ajar terdapat panduan pemberdayaan tersebut. Tahap terakhir adalah controling atau pengawasan. Dalam pemberdayaan dikenal istilah monitoring dan evaluasi. Bagaimana keberlanjutan pemberdayaan sesudah dilakukan terminasi. Apakah ada perubahan terjadi pada keluarga duafa tersebut, apakah perlu reempowerment ? Semua tahap ini dalam proses pembelajaran merupakan tanggung jawab tenaga pendidik jika memang kuliah lapangan menggunakan pendekatan pemberdayaan. Jika tidak, kuliah lapangan hanya sekedar pemberian bantuan kesejahteraan sosial; sekalipun pada buku ajar tidak dibolehkan mahasiswa memberi uang melainkan harus berupa barang - ibarat konsep pekerjaan sosial klasik; memberi pancing - yang bisa dipakai untuk mencari Ikan.

\section{Produck Evaluation (Evaluasi Produk)}

Tujuannya untuk pengukuran, membuat interpretasi dan mengevaluasi capaian program (Stufflebeam \& Shienfield, 1985:176). Product Evaluation yaitu mengukur capaian keberhasilan. Juga pengumpulan deskripsi dan evaluasi terhadap luaran (outcome) dan mengintegrasikan semua itu untuk membuat interpretasi keberhasilan program.

Bisa dikerjakan dengan menyusun definisi operasional dan membuat alat ukur yang sudah dicapai (objektif), melalui koleksi nilai dari stakeholder, melalui unjuk kerja (performing) baik memakai analisis kuantitatif, maupun kualitatif

Sebagai pembanding, analisa produk dibutuhkan antara tujuan, yang dipakai dalam desein serta capaian program . Hal yang dinilai bisa skor tes, prosentase, observation data, data diagram, sosiometri dan lain-lain yang bisa hubungannya dengan tujuan. Seterusnya dibuat analisa mengapa hasilnya seperti itu.

Mengukur keberhasilan pencapaian tujuan. Mengumpulkan deskripsi dan penilaian terhadap luaran (outcome) dan membangun hubungan dengan objektif, konteks, input, dan informasi, proses, serta untuk menginterpretasikan kelayakan dan keberhargaan program.

Evaluasi bisa dilakukan dengan membuat definisi operasional dan mengukur kriteria pengukuran yang telah dicapai (objektif), melalui pengumpulan nilai dari stakeholder, dengan unjuk rasa (performing) baik dengan memakai analisis secara kuantitatif, maupun kualitatif

Ini diperlukan sebagai pembanding antara tujuan, yang ditetapkan dalam rancangan dengan hasil program yang dicapai. Hasil yang dinilai dapat berupa skor tes, prosentase, data observasi, diagram data, sosiometri dan sebagainya yang bisa ditelusuri kaitanya dengan tujuan-tujuan yang lebih rinci. Selanjutnya dilakukan analisis kualitatif tentang mengapa hasilnya seperti itu.

Terkait dengan evaluasi produk dalam penelitian ini, di mana mahasiswa adalah sebagai produk yang harus dinilai di 
dalam evaluasi ini. Penilaian disini tidak mengukur capaian, melainkan perubahan apa yang terjadi pada diri mahasiswa akan pemahaman terhadap Muhammadiyah. Berdasarkan wawancara dengan beberapa informan mahasiswa diperoleh temuan bahwa mereka akhirnya mengenal Muhammadiyah dari dalam. Sebelumnya pandangan tentang Muhammadiyah berbeda sebelum masuk UHAMKA. Misalnya Muhammadiyah itu tidak membaca qunut, tidak membaca ushalli di dalam sholat, tidak membiasakan sholawat badriyah, sholawat nariyah, tidak pake bacaan sayyidina dan lainlain. Setelah mereka jadi mahasiswa dan diberi penjelasan oleh para dosen, akhirnya mereka megerti mengapa Muhammadiyah tidak menggunakan qunut, ushalli, sholawat dan lain-lain.

Dari pengalaman memberdayakan keluarga duafa, mereka jadi mengerti bahwa Islam di organisasi Muhammadiyah bukan hanya sekedar ibadah yang berdimensi vertikal, melainkan juga berdimensi horizontal dalam bentuk peduli pada lingkungan, orang-orang miskin sebagaimana dicontohkan oleh $\mathrm{KH}$ Ahmad Dahlan dalam menjelaskan surat Al Maaun kepada jamaah pengajiannya. Jadi dalam konteks evaluasi produk, itulah bentuk hasil produk yang dihasilkan dari mahasiswa yaitu pemahaman terhadap Muhammadiyah.

\section{KESIMPULAN}

Hasil penelitian menunjukkan, pertama, dari sisi konteks, kendala yang dihadapi dalam pembelajaran Kemuhammadiyahan telah dijawab dengan mengadakan pembaharuan pembelajaran Kemuhammadiyahan. Pembaharuan ini setidaknya dapat dilihat dari dua hal, yaitu diterbitkannya buku ajar baru yang siap digunakan oleh para tenaga pendidik/dosen, dan dilakukan penilaian dan pembinaan Tenaga pendidik/dosen Al Islam dan Kemuhammadiyahan.

Kedua, dari sisi input, permasalahan yang dihadapi adalah rendahnya jenjang jabatan akademik dosen. Jenjang jabatan yang dimiliki dosen pengampu mata kuliah Kemuhammadiyahan adalah Asisten Ahli dan Lektor. Belum ada Lektor Kepala, apalagi Guru Besar. Di samping itu, terdapat juga kendala terkait pembiayaan. Dengan penerapan strategi pembelajaran baru, yaitu implementasi teologi al Maun berupa pemberdayaan keluarga miskin sebagai strategi pembelajaran yang diandalkan, diperlukan biaya yang tidak sedikit.

Ketiga, dari sisi proses, pembelajaran Kemuhammadiyahan seperti dijelaskan di atas ditemukan beberapa kelemahan, yaitu terkait durasi waktu pembelajaran. Beberapa dosen mengatakan tidak cukup hanya dengan 2 sks mengelola pembelajaran dengan strategi pemberdayaan masyarakat yang berbasis pada teologi al-Maun Kiyai Dahlan.

Keempat, dari sisi produk, mereka akhirnya mengenal Muhammadiyah dari dalam. Sebelumnya pandangan tentang Muhammadiyah berbeda sebelum masuk UHAMKA. Misalnya Muhammadiyah itu tidak membaca qunut, tidak membaca ushalli di dalam sholat, tidak membiasakan sholawat badriyah, sholawat nariyah, tidak pake bacaan sayyidina dan lain-lain. Setelah mereka jadi mahasiswa dan diberi penjelasan oleh para dosen, akhirnya mereka megerti mengapa Muhammadiyah tidak menggunakan qunut, ushalli, sholawat dan lain-lain.

\section{REFERENSI}

A J, Nitko \& Brookhart, SM. 2011. Educational Assessment of Students, Boston, Pearson Education, Inc

Abbas, Shahrizal. 2014. Manajemen Perguruan Tinggi, Prenadamedia group Rawamangun Jakarta

Ad-Dumaiji Abdullah. 2016. Konsep Kepemimpinan Dalam Islam, Ummul Qura, Cipayung Jakarta

Ahmad, Hasan. 2006. Perguruan Muhammadiyah Padang Panjang, dalam Suara Muhammadiyah No.17, 16-31 Agustus 2006 
Alfitri. 2011. Community Development; Teori dan Praktek. Yogyakarta: Penerbit Pustaka Pelajar.

Ali, Muhammad. 2016. "Pendidikan Muhammadiyah" dalam Jurnal Studi Islam Profetika, Vol 17 No.1 Juni 2016

Amie Primani dan Khairunnas. 2013. Pendidikan Holistik: Format baru Pendidikan Islam membentuk karakter paripurna. Jakarta: al-Mawardi Prima.

Amir, Mohammad Faisal. 2016. Manajemen Perguruan Tinggi, Penerbit Mitra Wacana Media, Jakarta

Arifin, Samsul. 2015. "Rekonstruksi AIK PTM Sebagai Praksis Pendidikan Nilai, Jurnal Edukasi Volume 13 Nomor 2 Agustus2015

Arifin, Zainal. 2011. Evaluasi Pembelajaran, teknik - prosedur. Bandung: PT. Remaja Rosda karya.

Arsyad, Lincolin. 2016. "Konsolidasi PTM/PTA yang kuat, berdaya saing dan berkemajuan, Warta PTM Edisi Maret - April 2016

Arum, Richard, and Josipa Roksa. 2011. Academically Adrift: Limited Learning on College Campuses, Cicago: Universitu of Cicago Press

Azhar Muhammad, dkk 2000. Pemikiran Keislaman Muhammadiyah; Antara purifikasi dan dinamisasi, LPPI UMY

Aziz, Safrudin. 2016. Manajemen Mutu Perguruan Tinggi; Koreksi dan Implementasi, Penerbit Gavamedia

Azra, Azyumardi 2013. Kelas Menengah Baru Muslim, Sebuah Survey ke arah format Dakwah alternatif dalam Ilham Mundzir dan Faozan Amar (Ed). Muhammadiyah dan dakwah Pencerahan. Jakarta: AlWasat
Bakri, Masykuri, Hilmy Masdar. 2016. Dinamika Pendidikan Islam, diterbitkan oleh Madani, Malang

Burhani, Ahmad Najib. 2010. Muhammadiyah Jawa. Ciputat: Al Wasat Publishing House.

Gandara Ridza. 2012. Kehebatan Islam dalam Pendidikan. Penerbit Edutama Publishing

Hanafi, Yusuf. 2016. Transformasi Kurikulum Pendidikan Agama Islam di Perguruan Tinggi Umum: Paradigma Normatif Doktriner menuju Historis Kontekstual. Jurnal Pendidikan dan Pembelajaran Universitas Negeri malang Volume 23 Nomor 1, April 2016.

Hikmat, Harry. 2010. Strategi Pemberdayaan Masyarakat. Penerbit Humaniora Utama Press.

Husaini, Adian. 2012. Pendidikan Islam Membentuk Insan berkarakter \& Beradab, Jakarta: Cakrawala Publishing.

Ife, Jim dan Tesoriepo Frank. 2008. Community Development; Alternatif Pengembangan Masyarakat di era globalisasi. Yogyakarta: Penerbit Pustaka Pelajar.

Ilyasin, Mukhamad, Nurhayati Nanik. 2012. Manajemen Pendidikan Islam, Malang: Aditya Media Publishing.

Latif, Hilman. 2010. Melayani Umat; Filantropi Islam dan Ideologi Kesejahteraan Kaum Modernis. Jakarta: PT Gramedi.

Suradika, A., Winata, W., Wicaksono, D., Hadi, M. S., \& Rifqiyati. (2020). The Influence of Instructional Materials and Educational Background on the Learning Outcomes of Islamic Education. Solid State Technology, 63(6), 1027-1043.

Suradika, A., Dirgantara Wicaksono. 2019. Metodologi Penelitian. 
Tangerang Selatan: UM Jakarta Press.

Suradika, Agus.2000. Metode Penelitian Sosial. Jakarta: UMJ Press
Suradika, Agus. 2019. Pendidikan Keluarga dan Keluarga Berpendidikan: Perspektif Islam. Jakarta: Direktorat Advokasi dan KIE BKKBN. 